\title{
IMPACT OF COMPETITIVE FORCES TO THE CONTRACTORS IN SRI LANKA: AN INDUSTRY ANALYSIS USING PORTER'S FIVE FORCES
}

\author{
INDRARATHNE. P.K.G. ${ }^{1}$, RANADEWA. K.A.T.O. ${ }^{2} \&$ SHANIKA V.G. ${ }^{3}$ \\ 1, 2, 3 University of Moratuwa, Katubedda, Sri Lanka \\ ${ }^{1}$ kavindyagayathree28@gmail.com, ${ }^{2}$ tharusharanadewa@yahoo.com, ${ }^{3}$ shanikav@uom.lk.
}

\begin{abstract}
The nature of the business environment is very complex in the construction industry. Huge capital investment, supply chain management, resource scarcity and uncertainty create a multifaceted background along with impressive external environmental impacts. Thus, contracting organizations are highly influenced by the competitive nature of the construction industry. Hence identifying the impact of competitive forces to the contractors in Sri Lanka is identified as vital. Besides, Porter's five competitive forces model is grounded to interpret the competition through external environment and it denotes that there are five forces which can affect to the competition of an industry; new entrants, suppliers, buyers, substitutes and the existing competitors. Thus, the research leads to examine the impact of competitive forces to the contractors in Sri Lanka using a comprehensive Porter's Five Forces analysis. The research employs a quantitative approach consisting of preliminary survey of experts and questionnaire survey with the participation of construction experts in Sri Lanka. In order to analyse the collected data, statistical tools such as RII method and measurements of central tendency were employed. The results of the analysis elicited 28 significant factors that determine the power of the five competitive forces on local contractors. Accordingly, the final outlined Porter's five forces analysis matrix enables the contractors to analyse the impact of each competitive force through identified determinant factors which would provide a proper guidance on determining necessary offensive or defensive strategies to be taken to survive in the market.
\end{abstract}

Keywords: Porter's five forces; Construction industry; Contractors; Competitive environment

\section{Introduction}

The productivity of the construction industry has significant impact on the economic growth of any country (Amarasekara, 2018). However, the construction industry is one of the main pillars in the Sri Lankan economy. In recent past, there has been an upward trend of construction activities in Sri Lanka creating a competitive environment inside the construction industry, especially among contractors (Perera et al., 2019). Moreover, due to the foreign contractors' incorporation in the construction industry, Chinese and Indian contractors in Sri Lanka with the possession of an adequate number of craftsmen, labour force, machinery and finance place them in a comparative advantageous situation over Sri Lankan local contractors (Amarasekara, 2018). Hence, the existing competitive environment among contractors can be identified. Hence, to determine accurate and appropriate business strategies to the situation, it is necessary to recognize the nature of the changing business environment and market competition. A firm's strategic planning decisions are greatly affected by the environ-mental forces in the firm's operating market (Korkmaz \& Messner, 2008; Porter, 2008).

Therefore, in 1979, Michael E. Porter introduced "Porter's five forces" to formulate competitive strategies to different sectors as it was a revolution in the business strategy field (Porter, 2008). Therefore, it is a sensible and appropriate tool to analyse the market competition in the construction industry. In doing so, Porter's five forces could be used to identify the industry competition through five forces namely, new entrants, buyers, suppliers, substitutes and existing rivals. Although local contractors are often affected by the market competition and competitive forces, no such study has been carried out yet in the local context, especially considering Porter's five forces. Even though industry competition influence on company's profitability and its survival within the industry through competitive forces as mentioned in Porter's five forces, lack of researches can be identified in the research lexicon due to the existing gap. Thus, the requirement has arisen to identify the strength of each competitive force as to ultimately develop Porter's five forces analysis for the construction industry in Sri Lanka. 


\section{Literature Review}

A comprehensive literature on Porter's Five Competitive Forces in construction industry is carried out considering each competitive force namely, rivalry among existing firms including power of the suppliers, power of the buyers, the threat of substitutes and threat of new entrants as discussed below.

\subsection{REVIEW OF PORTER'S FIVE COMPETITIVE FORCES IN CONSTRUCTION INDUSTRY}

Gnjidic (2018) explains, insufficient analysis of the business environment can create bias situations in the company's strategic planning process. Further, identification of the company's position in its micro- environment could be helpful to define strengths, weaknesses, opportunities and threats which will affect the profitability of the company. These five forces denote rivalry among existing firms including power of the suppliers, power of the buyers, the threat of substitutes and threat of new entrants as shown in figure 01.

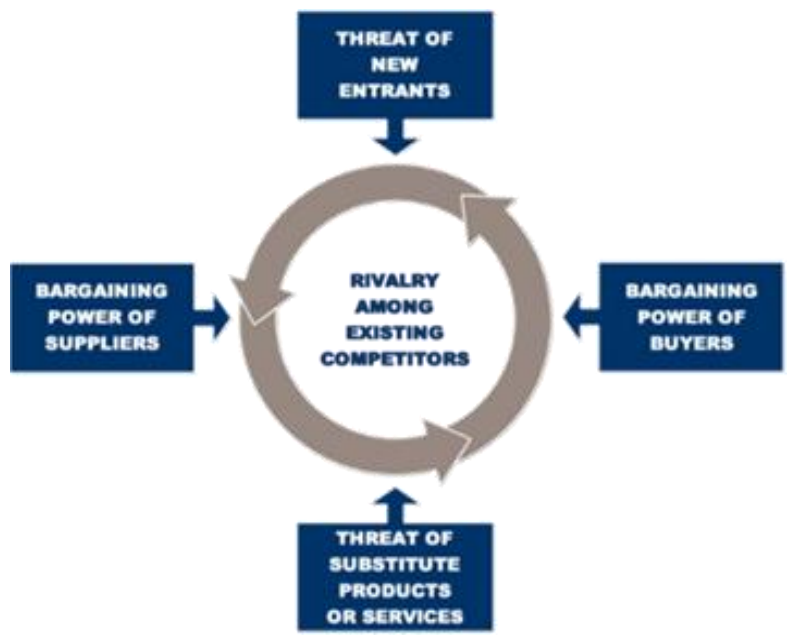

Figure 1, Porter's five forces framework (Source: Porter,20o8)

The market competitiveness is being influenced by these five forces and thus, collective power of all forces finally defines the potential profit (Korkmaz \& Messner, 2008; Eskandari et al., 2015). Therefore, Porter's five forces model can be used to analyse the competitiveness in current business environment in the construction industry as discussed below.

\subsubsection{Threat of new entrants}

According to Eskandari et al. (2015), when new entrants arrive into the market, they are willing to acquire a portion of market share and thus, establishing new capacities. As they accelerate industry competition consequently, it could bring down other company's profitability (Mathooko \& Ogutu, 2015). Hence, in Sri Lanka, there are several government regulations to be followed by new entrants when entering into the construction industry as contractors. As per CIDA, there is a specific national registration and grading scheme for construction contractors. Moreover, CIDA registration is a mandatory requirement to obtain government contracts which would create a challenging situation for a new contractor. Further, the changes in political policies such as free trade agreements could provide local firms, the opportunity to enter the international market (Korkmaz \& Messner, 2008). Therefore, new entrants have both barriers and opportunities while entering to the market.

\subsubsection{The power of suppliers}


The construction industry is a supplier dominated industry (Kale \& Arditi, 2002) and construction companies are usually dealt with construction materials, equipment and etc. The building material prices are often rising due to currency devaluation and inflation in Sri Lanka (Weddikkara \& Devapriya, 2000). The government has granted duty free material imports which has restricted the domestic manufactured cement prices (Weddikkara \& Devapriya, 2000). According to BOI (2019), import volume indices of investment goods and building materials has been increased by $20 \%$ to $23 \%$ in 2016 denoting the positive expansion of the construction industry in Sri Lanka. Hence the power of material suppliers is a critical factor in the competitive construction industry.

Companies have various supplier groups to obtain their inputs including labour suppliers as a key category. Non availability of skilled workforce has become a critical issue in the current construction industry (De Silva, et al., 2014) and thus, the labour suppliers have become more powerful by setting higher prices due to the higher demand (Eskandari et al., 2015). Finance as a significant factor related to suppliers in the construction firms (Amarasekara, 2018; Bandara, 2014), suppliers are paid through fund expansions, purchasing fixed assets and funding working capital requirements in the company (Department for Business Innovation and Skills, 2013). Therefore, suppliers have spread their power drastically in the construction industry.

\subsubsection{The power of buyers}

In the construction industry, government acts as a major client or a market intervener (Ericsson, et al., 2005). It influences the demand of the construction industry by changing fiscal and monetary policies. According to Bandara (2014), complex and special kind of projects require especially capable contractors who are limited within the industry. In such situations, customers' bargaining power will be neglected in Sri Lanka. Central Government Ministries, Authorities, Departments, Provincial Councils and Local Government Authorities are public sector clients of the construction industry and their role is vital (Gunawardhana \& Jayalath, 2017). Thus, client as the most influential character in the project procurement can directly impact to the contractors.

\subsubsection{The threat of substitutes}

According to the recent publication of CCISL (Chamber of Construction Industry Sri Lanka, 2019), modular construction has been one of the trends that has shaped commercial construction in 2019. As an example, prefabricated building components and modular building systems has become an accepted solution for the scarcity of skilled labour in traditional Sri Lankan construction industry (Gunawardena et al., 2016). Therefore, availability of substitutes has a considerable impact towards the market competition. Moreover, substitutes can be highly invented with the advanced technologies.

\subsubsection{Rivalry between existing competitors}

Construction contracting has become more competitive due to the tender selection procedures and thus, the tender price should be included with a lower profit margin to win the projects in a typical scenario (Hampson \& Kwok, 1997). Under this force, market rivalry means competitive intensity in terms of competition among local and international companies (Eskandari, et al., 2015). Abidin et al. (2008), stated that the domestic contractors face complications when competing with foreign contractors due to their relatively lower financial capabilities.

Even though foreign collaboration enhances local construction capacity by knowledge and technology transferring (Bandara, 2014), later it has also become an unfair competition to the local contractors (De Silva et al., 2014). Thus, the construction market rivalry between contractor organizations has been increased. Therefore, there is an intense competition between contractors with each other to obtain the construction projects. 
Since the literature identifies various factors to be considered under all competitive forces as discussed before, Table 1 indicates the Porter's five forces and the determining factors under each force derived through literature.

Table 1, Significant Factors in The Sri Lankan Construction Industry

\begin{tabular}{|c|c|c|}
\hline \multicolumn{3}{|c|}{ Threat of New Entrants } \\
\hline & Factors (Entry barriers) & \\
\hline 1 & Capital requirement & \multirow{7}{*}{$\begin{array}{l}\text { (Porter, 2008; Mathooko \& } \\
\text { Ogutu, 2015; Eskandari et } \\
\text { al., 2015) }\end{array}$} \\
\hline 2 & Contractors' ability to access to distribution channels & \\
\hline 3 & Government and other restrictive policies & \\
\hline 4 & Competitors' reaction & \\
\hline 5 & Contractor's economies of scale & \\
\hline 6 & Customers' benefit from economies of scale & \\
\hline 7 & 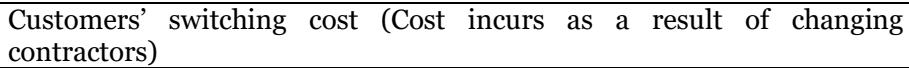 & \\
\hline \multicolumn{3}{|c|}{ The Power of Suppliers } \\
\hline & Factors & References \\
\hline 1 & Supplier's input is critical for the production & \multirow{7}{*}{$\begin{array}{l}\text { (Porter, 2008; Mathooko \& } \\
\text { Ogutu, 2015; Eskandari et } \\
\text { al., 2015) }\end{array}$} \\
\hline 2 & Suppliers' concentration in the industry & \\
\hline 3 & Non-Availability of substitutes for suppliers' products/services & \\
\hline 4 & Suppliers' product differentiation & \\
\hline 5 & Suppliers with more important customers & \\
\hline 6 & Forward integration & \\
\hline 7 & Contractors' switching cost & \\
\hline \multicolumn{3}{|c|}{ The Power of Buyers } \\
\hline & Factors & References \\
\hline 1 & Number of buyers in the market & \multirow{6}{*}{$\begin{array}{l}\text { (Porter, 2008; Mathooko \& } \\
\text { Ogutu, 2015; Eskandari et } \\
\text { al., 2015) }\end{array}$} \\
\hline 2 & Product standardization and differentiation & \\
\hline 3 & Availability of large-volume buyers & \\
\hline 4 & Vitality rate of the product/service & \\
\hline 5 & Buyer's switching cost & \\
\hline$\frac{5}{6}$ & Backward integration & \\
\hline \multicolumn{3}{|c|}{ The Threat of Substitutes } \\
\hline & Factors & References \\
\hline 1 & Price- performance trade off & \multirow{3}{*}{$\begin{array}{l}\text { (Porter, 2008; Mathooko \& } \\
\text { Ogutu, 2015; Eskandari et } \\
\text { al., 2015) }\end{array}$} \\
\hline 2 & Availability of substitutes & \\
\hline 3 & Switching cost to the substitutes & \\
\hline \multicolumn{3}{|c|}{ Rivalry among Existing Competitors } \\
\hline & Factors & References \\
\hline 1 & Contractors with equal size and power & \multirow{7}{*}{$\begin{array}{l}\text { (Porter, 2008; Mathooko \& } \\
\text { Ogutu, 2015; Eskandari et } \\
\text { al., 2015) }\end{array}$} \\
\hline 2 & Concentration of the contractors in the industry & \\
\hline 3 & Industry growth rate & \\
\hline 4 & Product differentiation & \\
\hline$\frac{7}{5}$ & Switching cost of buyers & \\
\hline 6 & Exit barriers from the industry & \\
\hline 7 & High fixed cost and low marginal cost & \\
\hline
\end{tabular}

However, it is necessary to recognise appropriateness of each factor to the Sri Lankan construction industry in order to decide power of each force in the local context. In doing so, prevailing influence of each factor on the contractors is required to be analysed in depth.

\section{Research Methodology}

Amarasekara (2018) describes, a quantitative approach is most suited for assessing the relationships among different variables using statistical and graphical tools. The study consists of predetermined list of factors which requires to determine the significant factors to the Sri Lankan construction industry based on the values derived through statistical analysis. Therefore, quantitative data approach is best suited for the study.

Primarily, a comprehensive literature review was carried out to discuss on the Porter's five forces and to identify the determining factors under each force through the survey of books, journal articles, periodicals, conference proceedings, annual reports and etc. Then a preliminary expert survey was 
conducted with the participation of three experts to refine determining factors of from five forces within the Sri Lankan context and to further identify any additional factors relating to the context. Based on derived factors through preliminary survey, a questionnaire was prepared and the distributed among 161 experts who are working in the contractor organizations with more than 5-year experience in construction industry and yet, 108 was responded. Respondents were asked to determine the significance of each factor in the given criteria using the Likert scale from 1-5.

To ensure a better demonstration of the competitive nature of the current Sri Lankan construction context, the study was limited to the participants from contractor organizations having $\mathrm{C} 1, \mathrm{CS} 1$ or CS2 grading to collect data. The convenience sampling method was used to collect the data considering the easiness to reach the questionnaire respondents as the selected respondents represent the total population. Subsequently, RII (Relative Important Index) was used to analyse the collected data and thus, to identify the most significant determining factors under each competitive force considering the Sri Lankan context.

\section{Data Analysis and Research Findings}

Based on the findings of preliminary survey, the existing factors derived through literature were refined within the Sri Lankan context and additional factors were also suggested as shown in the Table 2. Factors R1, R2, R3, R4, R5, R6, R7, R8 \& R9 were rejected as the determining factors of Porter's five forces in the Sri Lankan construction industry. Further, 07 additional factors exist in the current industry were suggested which are illustrated in the Table 2. The refined list of factors was considered to be applicable within the local context.

The analysis of the questionnaire survey findings demonstrates the relative importance (RII) of each factor under all five competitive forces which is summarized in table 2. Thus, all factors were ranked based on their RII value considering their applicability in the Sri Lankan context to determine competitiveness among contractors.

Table 2, Determining factors of Porter's five forces

\begin{tabular}{|c|c|c|c|}
\hline \multicolumn{4}{|c|}{ Threat of New Entrants } \\
\hline & Factors (Entry barriers) & RII & Rank \\
\hline S1 & Capital requirement & $87 \%$ & 1 \\
\hline S2 & Contractors' ability to access to distribution channels & $79 \%$ & 2 \\
\hline S3 & Government and other restrictive policies & $77 \%$ & 3 \\
\hline $\mathbf{S 4}$ & Competitors' reaction & $71 \%$ & 4 \\
\hline A1 & Corruption & $70 \%$ & 5 \\
\hline R1 & Contractor's economies of scale & & \\
\hline R2 & Customers' benefit from economies of scale & & \\
\hline $\mathrm{R} 3$ & $\begin{array}{l}\text { Customers' switching cost (Cost incurs as a result of changing } \\
\text { contractors) }\end{array}$ & & \\
\hline \multicolumn{4}{|c|}{ The Power of Suppliers } \\
\hline & Factors & RII & Rank \\
\hline S5 & Supplier's input is critical for the production & $88 \%$ & 1 \\
\hline S6 & Suppliers' concentration in the industry & $82 \%$ & 2 \\
\hline S7 & Non-Availability of substitutes for suppliers' products/services & $81 \%$ & 3 \\
\hline S8 & Suppliers' product differentiation & $77 \%$ & 4 \\
\hline S9 & Suppliers with more important customers & $76 \%$ & 5 \\
\hline A2 & Product recommendation from Employer/Consultant & $75 \%$ & 6 \\
\hline A3 & Only affordable good technology option & $74 \%$ & 7 \\
\hline A4 & Availability ex stock & $71 \%$ & 8 \\
\hline A5 & Proven and time-tested products & $71 \%$ & 9 \\
\hline R4 & Forward integration & & \\
\hline $\mathrm{R} 5$ & Contractors' switching cost & & \\
\hline \multicolumn{4}{|c|}{ The Power of Buyers } \\
\hline & Factors & RII & Rank \\
\hline S10 & Number of buyers in the market & $85 \%$ & 1 \\
\hline S11 & Product standardization and differentiation & $83 \%$ & 2 \\
\hline $\mathbf{S 1 2}$ & Availability of large-volume buyers & $81 \%$ & 3 \\
\hline
\end{tabular}




\begin{tabular}{|c|c|c|c|}
\hline S13 & Vitality rate of the product/service & $80 \%$ & 4 \\
\hline A6 & Repetitive buyers & $74 \%$ & 5 \\
\hline A7 & Early payment scheme of buyers & $71 \%$ & 6 \\
\hline R6 & Buyer's switching cost & & \\
\hline $\mathrm{R} 7$ & Backward integration & & \\
\hline \multicolumn{4}{|c|}{ The Threat of Substitutes } \\
\hline & Factors & RII & Rank \\
\hline S14 & Price- performance trade off & $79 \%$ & 1 \\
\hline S15 & Availability of substitutes & $78 \%$ & 2 \\
\hline S16 & Switching cost to the substitutes & $74 \%$ & 3 \\
\hline \multicolumn{4}{|c|}{ Rivalry among Existing Competitors } \\
\hline & Factors & RII & Rank \\
\hline $\mathbf{S 1 7}$ & Contractors with equal size and power & $91 \%$ & 1 \\
\hline S18 & Concentration of the contractors in the industry & $82 \%$ & 2 \\
\hline S19 & Industry growth rate & $81 \%$ & 3 \\
\hline S20 & Product differentiation & $74 \%$ & 4 \\
\hline S21 & Switching cost of buyers & $71 \%$ & 5 \\
\hline $\mathrm{R} 8$ & Exit barriers from the industry & & \\
\hline R9 & High fixed cost and low marginal cost & & \\
\hline
\end{tabular}

\begin{tabular}{|l|l|l|l|l|l|}
\hline S & Selected & R & Rejected & A & Additional \\
\hline
\end{tabular}

There are five relevant entry barriers incorporated under the first competitive force in order to identify the threat from new entrants. Among them, "Corruption" has been identified as a new factor that acts as an entry barrier in this industry. Further, Capital requirement is identified as most important factor among all factors. Accordingly, these entry barriers restrict the entrance of new contractors in Sri Lankan construction industry.

Altogether there are nine factors that could influence the power of suppliers including four new factors identified through the preliminary respondents. As De Silva et al. (2014) stated that non availability of resources would increase the power of suppliers whereas the study also agrees with the statement by denoting "non-availability of substitutes for the suppliers' products or services" as the most critical factor. However, forward integration and contractors' switching cost were rejected considering the expert opinion.

The third force "power of buyers" demonstrates six determining factors in local context including "Repetitive buyers" and "Early payment schemes of buyers" as new factors. Referring to the literature, construction industry has large scale buyers who claim to have more power to bargain with the contractors (Gunawardhana \& Jayalath, 2017) which is further proved through the findings of questionnaire survey reporting the highest RII value by the factor "Number of buyers in the market".

Fourth force "threats of substitutes" stay remains with three determining factors identified through literature even after the preliminary expert survey. The factors "Price- performance trade off" and "Availability of substitutes" could be further backed up through the literature, exemplifying the extensive applicability of prefabricated building components and modular building systems in current local construction industry due to their cost effectives (Chamber of Construction Industry Sri Lanka, 2019). Ultimately, fifth force deliberates about " the competition between existing contractors" with five key determinants under it. Referring to literature, presence of large number of foreign construction firms has caused to increase the competition between domestic contractors (De Silva et al., 2014; Bandara, 2014) which agrees upon the study findings.

Afterwards, each competitive force was assessed considering form of current prevailing influence on the contractors. Thus, respondents were asked to indicate the current influence of each force in the form of either positive, negative or neutral. However, based on the mode value calculations, findings denoted that all the forces except "threat of new entrants" make a 'positive' impact on the contractors in the local construction industry while "threat of new entrants" reports a neutral impact based on the 
mode values. Thus, resembling the study findings so far, develop Porter's five forces analysis was developed for the construction industry in Sri Lanka.

Thus, the current influence of the Porter's five forces through each relevant factor to the contractors in Sri Lanka is denoted in the figure 2. Initially, the figure 2 explores the external environment and it begins from the macro environment. Subsequently, the industrial environment is denoted under the five key determinants namely, new entrants, suppliers, buyers, substitutes and the existing competitors. Porter's five competitive forces are initiated from these elements and those five forces could be further elaborated with the derived determining factors considering the local construction industry. Altogether 28 determining factors were identified under all five forces.

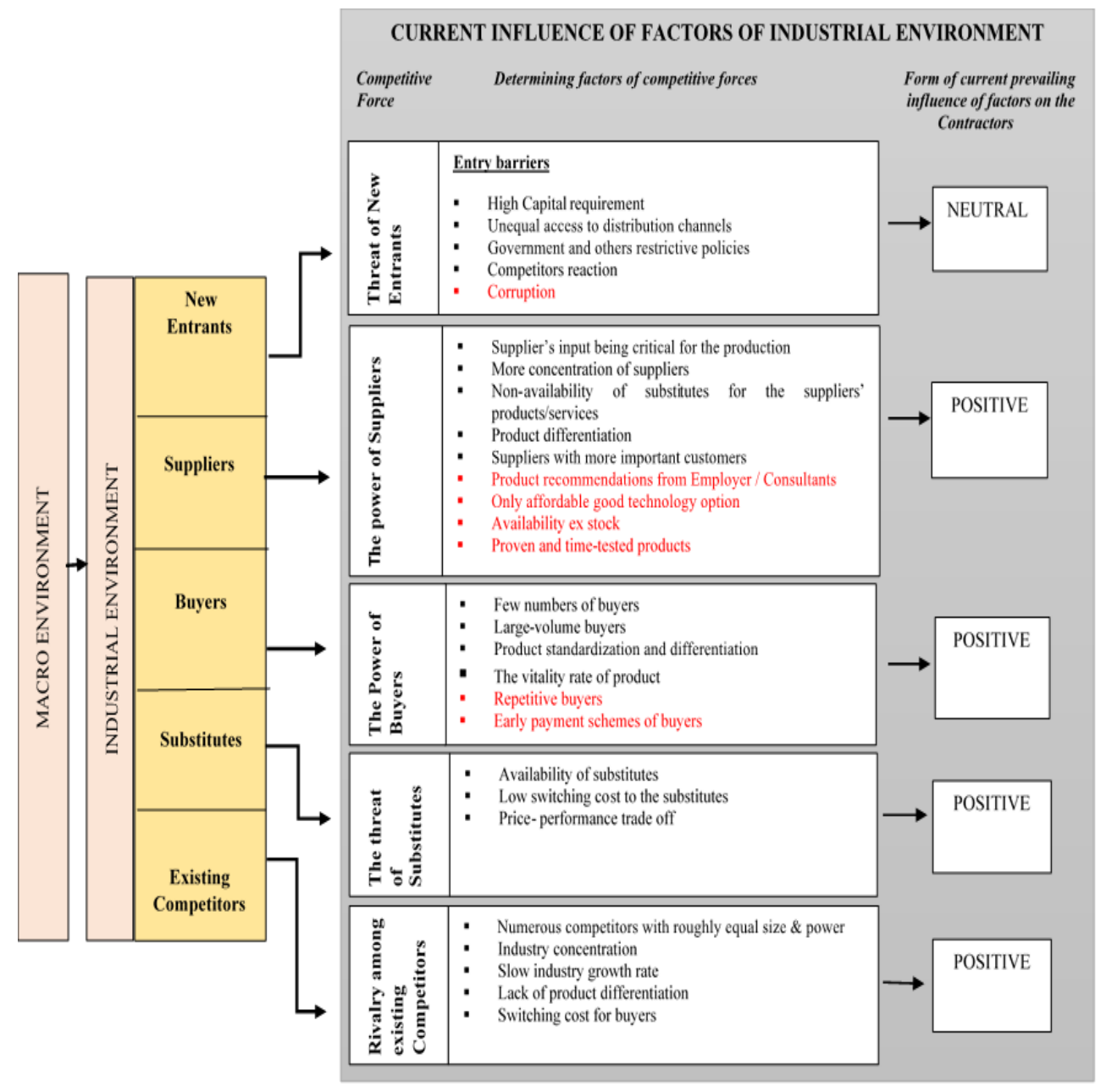

Figure 2, Porter's five forces analysis for contractors in current construction industry in Sri Lanka

Thus, the Porter's five forces analysis was developed identifying key determining factors related to local construction industry.

\section{Conclusions and Recommendations}

Competitive environment is a key determinant for the success of a construction business. The current construction industry has intense competitive environment whereas contractors compete with each other to acquire the projects. During last ten years, Sri Lanka has reached to an admirable development in residential, commercial, hotel and resort construction and infrastructure sectors. As a result, competitive environment among contractors has gradually been increased. 
Porter's five forces analysis elaborates that "existing competitors" is not the only factor that causes the competition. Evidently, there are four other factors, namely new entrants, suppliers, buyers and the substitutes. Hence, in order to determine competitiveness among contractors, all five key forces should be considered. Based on an extensive analysis carried for the Porter's five forces considering the Sri Lankan construction industry, 28 determining factors were denoted including seven additional factors derived through respondents' suggestions. Among those factors, some are identified as crucial to determine the competitive nature among Sri Lankan contractors; Capital requirement, Contractors' ability to access to distribution channels, Supplier's input, Number of buyers in the market, Product standardization and differentiation, Availability of substitutes, Contractors with equal size and power.

Hence, it is contractors' duty to consider all those factors to decide upon competitive strategies while overcoming challenges from existing competitors by confirming their survival in the industry. Considering the influence of each force on local contractors, only 'Threat of New Entrants' shown to be neutral. Besides all the other four forces, 'The Power of Suppliers', 'The Power of Buyers', 'The Threat of Substitutes' and 'Rivalry among Existing Competitors' have made positive influences on the contractors in the current local construction industry which would ultimately upsurge the competitiveness among the contractors, thus in the construction industry as a whole.

\section{References}

Abidin, I. S., Sudarto, Soepandji, B. \& Trigunarsyah, B. S., 2008. Identification of the cause of external factor problems that influence construction company's performance in Indonesia. Innovations in Structural Engineering and Construction.

Amarasekara, S., 2018. The impact on foreign contractors undertaking locally funded projects. Construction Review, Chamber of Construction Industry Sri Lanka, 30 August, 15(41).

Bandara, D. M., 2014. Impact of foreign contractors on development of Sri lankan construction industry through technology transfer. [Online] Available at: www.lib.mrt.ac.lk

Board of Investment of Sri Lanka, 2019. Large Scale Infrastructure. [Online] Available at: www.investsrilanka.com/sectors/large-scale-infrastructure/

Central Bank of Sri Lanka, 2018. Recent Economics Developments- Highlights of 2018 and Prospects for 2019, Colombo 01: Central Bank of Sri Lanka.

Chamber of Construction Industry Sri Lanka, 2019. 7 trends that will shape commercial construction in 2019. Construction Review, March.15(48).

De Silva, N., Fernando, E. \& Darmika, R., 2014. Impact of foreign workforce on productivity in foreign-funded infrastructure projects. Journal of Financial Management of Property and Construction, 19(2), pp. 168-183.

Department for Business Innovation and Skills, 2013. UK Construction: An economic analysis of the sector, London: Department for Business Innovation and Skills.

Ericsson, S., Henricsson, P. \& Jewell, C., 2005. Understanding construction industry competitiveness: the introduction of the Hexagon framework. s.l., s.n., pp. 188-202.

Eskandari, M. J., Miri, M., Gholami, S. \& Nia, S. R., 2015. Factors affecting the competitiveness of the food industry by using Porter's five force model case study in Hamadan province, Iran. Journal of Asian Scientific Research, 5(4), pp. $185-197$.

Gnjidic, V., 2018. Interdependence of company's industrial competitive position and it's strategic orientation: A dynamic theoritical model. Journal of Contemporary Management Issues, 23(2), pp. 103-121.

Gunawardena, T., Karunaratne, R., Mendis, P. \& Ngo, T., 2016. Prefabricated Construction Technologies for the Future of Sri Lanka's Construction Industry. Kandy, s.n.

Gunawardhana, T. \& Jayalath, A., 2017. Towards Sustainable Constructions: Trends in Sri Lankan Construction Industry-A Review. At Hilton Residences, Colombo-Sri Lanka, s.n., pp. 137-143.

Hampson, K. \& Kwok, T., 1997. Strategic Alliances in Building Construction: A Tender Evaluation Tool for the Public Sector. Journal of Construction Procurement, 3(1), pp. 28-41.

Kale, S. \& Arditi, D., 2002. Competitive Positioning in United States Construction Industry. Journal of Construction Engineering and Management, Volume 128, pp. 238-247.

Korkmaz, S. \& Messner, J. I., 2008. Competitive Positioning and Continuity of Construction Firms in International Markets. Journal of Management in Engineering, 24(4), pp. 207-216.

Mathooko, F. M. \& Ogutu, M., 2015. Porter's five competitive forces framework and other factors that influence the choice of response strategies adopteed by public universities in Kenya. International Journal of Educational Management, 29(3), pp. 334-354.

Perera, B. K., Wijewickrama, M. C., Ranaweera, W. S. \& Gamage, I. W., 2019. Significant factors influencing the bid markup decision of infrastructure projects in Sri Lanka. International Journal of Construction Management.

Porter, M. E., 2008. The five competitive forces that shape strategy. Harvard Business Review, pp. 25-41.

Weddikkara, C. \& Devapriya, K., 200o. The Sri-Lankan Construction Industry in the New Millennium. s.l., s.n. 